\title{
Elisabeth of Bohemia as a Naturalistic Dualist
}

Frederique Janssen-Lauret, University of Manchester

\section{Introduction}

Elisabeth of Bohemia was the first of Descartes' interlocutors to give a detailed statement of, and propose a solution to, the problem of mind-body interaction, and the only one to receive a detailed reply, unsatisfactory though she clearly found it. Elisabeth queried how an immaterial soul could, compatibly with the mechanistic physics she and Descartes endorsed, move or be moved by an extended body. She also tentatively suggested that the soul might be extended. Elisabeth's remarks on the topic are tantalisingly brief, and her letters are her only known philosophical works. Since we do not know how she would have expanded these suggestions into a philosophical treatise, it has been difficult to determine how we should extrapolate from her very compressed statements to a fully-fledged philosophical theory. Descartes appears to have taken Elisabeth's position as a confused version of his own, advising her to 'freely attribute this matter and this extension to the soul; for that is nothing but to conceive it united to the body' (Descartes to Elisabeth, 28 June 1643, repr. in Shapiro, 2007a, p. 71). Recent commentators have hailed Elisabeth instead as having a consistent and original metaphysic, not a handmaiden to, but a rival of, Cartesian dualism. Some interpret her as a materialist - principally Lisa Shapiro (2007b, pp. 41-3), who attributes to her a novel, non-reductive physicalism, but also Deborah Tollefsen (1999) who believes Elisabeth's solution to the mind-body problem is that of Hobbes and Gassendi. Others, especially Andrea Nye (1999, p. vii), regard her as proposing her own distinctive anti-dualist ontology. In this paper I present a new reading of Elisabeth as having a distinctive but dualist position, deriving from an effort to improve upon Descartes' metaphysics, and apparently informed both by a rejection of Scholasticism and by a kind of proto-naturalism, seeking a philosophy informed by the deliverances of the sciences.

A keen scholar of the new seventeenth-century mechanistic physics and an enthusiast of the gender-neutral and science-friendly aspects of Cartesian methodology, Elisabeth, I claim, took this method further than Descartes himself. In doing so she exposed some vestiges of the old ways which lingered in his system, and attempted alternative explanations which would dispense with them. What she objected to, I argue, was not dualism per se, but the residual Scholasticism of Descartes' account of mind-body causality and his dogmatism about principal attributes. She dismissed Descartes' Aristotelian story about our awareness of mind-body union, and his claim that mind-body causation can only be understood phenomenologically. Instead, Elisabeth pressed him further for a mechanistic explanation. She also challenged Descartes' categorisation of the 'action' of thought as mind's principal attribute, and his identification of it with the merely negative property of immateriality. Elisabeth held that the nature of the mind stood in need of further philosophical and empirical scrutiny. I problematise the materialist interpretation of Elisabeth with reference to later letters in which she rejected the Objections of Hobbes and Gassendi, and continued to urge further clarifications to Cartesian dualism on the mechanistic model. I explore Elisabeth's contrasting of statements of mechanistic physics with statements about thought, and her call for additional research into the properties of the mind, including by empirical means. On this basis I argue that she endorses a form of dualism, and suggest that she might be read as a naturalistic dualist, that is, a dualist who is open to philosophical conclusions being challenged and shaped by empirical results, and aims for philosophical and scientific investigation of the psychological and the physical to be brought into harmony.

\section{Elisabeth of Bohemia: Life and Works}

Elisabeth was born at Heidelberg Castle on 26 December 1618. Her parents were Elizabeth Stuart, the daughter of James I of England, VI of Scotland, and Frederick V Elector Palatine. ${ }^{1}$ When Elisabeth was a toddler, Frederick briefly became King of Bohemia as part of a revolt against the

${ }^{1}$ For a fascinatingly detailed biography of Elisabeth, see Shapiro 2007b, pp. 7-16. 
Holy Roman Empire. He lasted less than a year. The family fled to the Netherlands, where Elisabeth and her ten siblings were very well educated. Jacqueline Broad suggests that Elisabeth was taught by professors of the University of Leiden (Broad 2002, p. 16), and Shapiro conjectures that she was also tutored by Constantijn Huygens (Shapiro 2007b, p. 5). One of Elisabeth's sisters, Louise, was a well-known painter in her youth and in later life an abbess, who introduced Elisabeth and Malebranche. Another sister, Sophie, became electress of Hanover and patroness of Leibniz, whom she also introduced to Elisabeth. One brother, Rupert, was a notable chemist and - like several of the others - a military officer, while the eldest, Charles Louis, eventually gained back some of the Palatine land and revivified the University of Heidelberg.

Elisabeth was a tireless diplomat on behalf of her family. Involved in writing state letters for her mother from her late teens, she soon graduated to negotiating the release of Rupert, who had been made a prisoner of war while fighting on behalf of their uncle, Charles I. Such political activity was unusual for even the most educated of seventeenth-century women. Those who were not royalty were commonly advised to study politics only theoretically (van Schurman 1659, Shapiro $2007 \mathrm{~b}$, p. 4). Also unusual was Elisabeth's proficiency in the study of the new mechanistic physics and the latest developments in mathematics. She astounded Descartes with her proof, much more elegant than his own, in the emerging discipline of algebraic geometry (Descartes to Elisabeth, 17 November 1643, repr. in Shapiro 2007a, pp. 73-7). Her opinion was sought after by other professional mathematicians, too. John Pell advised a fellow scholar to study her proof (Shapiro 2007b, p. 13; Pell's letter is in the British Library, additional mss. 4365.f.198), and the University of Leiden took her advice on the appointment of the Cartesian mathematician van Schooten (Elisabeth to Descartes, 27 December 1645, repr. in Shapiro 2007a, pp. 88-91). Elisabeth was proficient in Latin and classical Greek and fluent in French, German and English. At one point in their correspondence we find her reassuring Descartes that Digby's English-language criticisms of the Dioptrics were based on a complete misinterpretation (Elisabeth to Descartes, 24 May 1645, repr. in Shapiro 2007a, pp. 172-4). She first wrote to Descartes in 1643, after reading the Meditations. They exchanged letters regularly until Descartes' death in 1650. Although I will focus on their discussion of dualism and mechanistic explanations, the correspondence covers an exceptionally wide range of philosophical topics, from physics and mathematics to Stoicism and moral philosophy. Descartes' exchanges with Elisabeth were clearly a significant influence on him. He dedicated his Principles of Philosophy to her in 1644, and developed themes from the correspondence into his Passions of the Soul. Elisabeth, for her part, provides in these letters the clearest and most extensive expression of her philosophical views which has been handed down to us. If she wrote any longer philosophical works, they have not survived, at least not under her own name. She expressed reluctance about sharing with the world even those views expressed in her letters, refusing publication of her side of the correspondence when Descartes had died and a volume of his letters was being planned. $^{2}$

Elisabeth remained politically active throughout her thirties, negotiating a younger sister's marriage and planning a diplomatic mission to see the Queen Mother of Sweden about the Treaty of Westphalia, a treaty which resulted in her family's securing a modest portion of the original Palatine lands (Elisabeth to Descartes July 1648 and 23 August 1648, repr. in Shapiro 2007a, pp. 1724). In her forties, Elisabeth chose a monastic life at the protestant convent in Herford, first as coadjutrix, and soon afterwards as abbess. In that capacity she offered sanctuary to Quakers, Labadists and other persecuted sects. She corresponded with Malebranche and Leibniz on philosophical themes, though never as extensively as she had with Descartes. Leibniz visited her on her sickbed in 1680. Elisabeth died soon afterwards, on 8 February.

\section{The Arguments of Descartes' Meditations and Elisabeth's Anti-Scholastic Perspective Upon Them}

Elisabeth's first few letters to Descartes concern the substance dualism he expresses in his Meditations. Descartes' quest for certainty in this work had led him to some radical breaks with the

${ }^{2}$ As a result, Elisabeth's letters were lost until the nineteenth century (Shapiro 2007b, p. 5). No full English-language edition was available until Shapiro's excellent translation appeared in 2007. 
Scholastic orthodoxy. The fact that mind-body dualism, the idea that the soul (or mind - like Descartes and Elisabeth, I will use the words interchangeably) is really distinct from the body, was one of them, is insufficiently appreciated. It is often supposed, in some vague way, that Christianity presupposes soul-body dualism ${ }^{3}$ and that the prevalence of Christianity in seventeenth-century Europe implies that dualism, too, must have been the prevailing view. In fact, the commonly held and orthodox Scholastic view was Aristotelian hylomorphism, according to which the soul is the substantial form of the body. A human being was thought to be some matter informed by a rational soul, not wholly a person after death until he or she is made whole again by the resurrection of the body (Pasnau 2011, p. 60). Part of my case in this paper will be that Elisabeth's views on the mindbody problem are inspired by anti-Scholasticism. She claimed as one advantage of her view that it makes one abandon the contradiction of the Scholastics, that it [the soul] is both as a whole in the whole body and as a whole in each of its parts' (Elisabeth to Descartes 1 July 1643, repr. in Shapiro 2007a, p. 72).

Descartes, who claims in the Meditations (rather dubiously) to demonstrate the immortality of the soul, is partly to blame for the misinterpretation that his dualism is just expounding mainstream Christianity. But the arguments he offers for the real distinction between mind and body, the argument from divisibility and the epistemological argument, are purely philosophical arguments, and they are so by design. Descartes deliberately proposed a philosophical method accessible to any rational creature, no matter her philosophical or religious education - a method Elisabeth enthusiastically embraced (Elisabeth to Descartes, 16 August 1645, repr. in Shapiro 2007a, pp. 99-101). I read Elisabeth's approach to mind and body, causality and the question of principal attributes as the result of what she views as a more consistent application of this Cartesian method, which includes the aim of making philosophical conclusions consistent with empirical investigation of the world. Like Broad (2002, p. 15), I think of Elisabeth as a Cartesian sympathiser in her philosophical approach and metaphysical outlook, but for different reasons from the ones Broad cites. Broad and other feminist scholars emphasise how Elisabeth's experiences as a woman shaped her views. I read Elisabeth, who was equally proficient in mathematics, physics and philosophy, as particularly drawn not just to Descartes' first philosophy but also to his attempts to connect philosophy to the new mechanistic science and its causal explanations. I see her as motivated by an opposition to Scholasticism, and by a kind of proto-naturalism, allowing empirical results to inform and call into question our philosophical preconceptions.

Descartes, now commonly regarded as a rationalist deeply invested in innate ideas and a priori knowledge, was also an active researcher working in several branches of science, and one who made efforts - some more successful than others - to make his philosophical views consistent with the latest discoveries. As we will see, he expended such efforts on his dualism as well as his views on matter and causality. Her letters suggest that Elisabeth considered Cartesianism a breath of fresh air compared to the old Scholastic ways. By 'Scholastic' I will mean only the late Scholasticism which dominated seventeenth-century intellectual life. In taking her perspective upon seventeenth-century Scholasticism on board without questioning it I of course do not mean to disparage Scholasticism, a broad and varied movement, in its entirety. Elisabeth's gender features less prominently in my interpretation than in those of, for instance, Harth (1992, p. 74), who attributes to Elisabeth a subjectivity-based feminist epistemology, Nye, who asserts Elisabeth's 'nondualist metaphysics of thinking body and material mind' (1999, p. xii) comes 'from the concerns of life, concerns of a young woman presented with challenges that taxed both soul and body' (1999, p. 12 ), and Broad, who regards Elisabeth's emphasis on the role of the body and the emotions as flowing from a woman's experience (2002, p. 15). Still, there is a feminist element to my antiScholastic reading of her, too. Elisabeth's preference for a method available to any rational thinker over one associated with the deeply conservative and sexist institutions of her time is likely connected to its capacity to take her seriously as a female reasoner. Aristotle's association of the masculine with reason, form and action, and of the feminine with matter and passivity, was frequently used as a justification for sexism by established scholars in the early modern period (King and Ra-

3 This vague supposition is so pervasive that several Christian philosophers now feel they have to defend at length the thesis that Christians need not be dualists. See Rudder Baker 1995 and van Inwagen 1978. 
bil, 2007, p. x-xi). By contrast, dualism has great potential as a metaphysical basis for gender equality (also see Ready 2002). The narrator of the Meditations might have any gender or none at all. As Cartesian meditators, we are all equally thinking things.

Although the real distinction between mind and body is not explicitly defended until the Sixth Meditation, like Margaret Dauler Wilson (1978, p. 71) I see the arc of Descartes' argument for our having an essentially thinking nature as beginning with the intrinsically first-personal move from 'cogito' to 'sum res cogitans' in the Second Meditation. With the certainty of 'I exist' firmly in place, the meditator explores her own attributes, aiming for knowledge of the same indubitable status not just of the existence of the self, but of its nature. She rejects an account of herself as the Aristotelian 'rational animal', of her characteristics as including nutrition and locomotion. All of these admit of doubt. Only the fact that she thinks, is conscious, is something she, first-personally, cannot doubt. Only this is something of which she can be certain that it belongs to her nature. One vexed question for Cartesian dualism is whether the meditator can be sure that cogitatio - generally translated 'thought', but according to Anscombe and Geach (1954) more correctly rendered 'consciousness' or 'experience' - is her only nature. Elisabeth asked a version of this question: could it be that the soul has multiple natures, that it is both conscious and extended? ${ }^{4}$

Raising the question of multiple natures is easily conflated with advocating materialism. I argue that in Elisabeth's case, it would be a mistake to infer materialism from her suggestion that the soul might possess both extension and consciousness. The inference from the soul's having multiple natures to the soul's being material relies on two hidden premises. The first is commonly taken for granted, but is nevertheless a substantial premise: that there are substances and attributes, and that the soul or mind is a substance, to which two natures are attributed. Materialism does not follow merely from attributing two natures to the soul. A second premise is needed: that the two natures are actually only one, that is, that the substance in question really only has a material nature.

Textual evidence suggests that Elisabeth had qualms about the second hidden premise. She certainly disavowed reductionism about mind and body. I read her letters as revealing further reservations about the first hidden premise, the Scholastically-inspired substance-attribute model. Although Elisabeth did not contest the existence of substances and attributes, she made interesting attempts to undermine Descartes' ontology of substance, attribute and mode. His ontology was modelled on Aristotle's as interpreted by the late Scholastics: substances, capable of independent existence, are each characterised by exactly one principal attribute, which manifests itself by its distinctive modes. ${ }^{5}$ Attributes and modes depend on the substance for their existence. Assuming this Scholastic ontology, no finite substance has multiple principal attributes, so the attribution of two natures to the soul will look like an unclear expression of dualistic mind-body union (as Descartes interprets Elisabeth) or like a kind of materialism, with extension taken to be the real principal attribute, and consciousness to be an accidental or emergent attribute (as Shapiro reads her). Elisabeth's point, in my view, was a more radical one, which challenged the underlying Scholastic ontology. As we will see, she expressed scepticism about the way Descartes defines the principal attribute and modes of the mind, especially about its being characterised in merely negative terms, as 'immateriality' or 'nonextendedness'. She appears to have allowed for the possibility of a finite mental substance with multiple principal attributes. If one substance can genuinely

${ }^{4}$ I use 'extension' here to mean spatial location, and not in the more rarified Scholastic sense of 'having parts outside parts', as opposed to being holenmeric, or 'whole in the whole and whole in the parts'. Although there is some scholarly debate about holenmerism in Descartes (Rozemond 2003), Elisabeth regarded holenmerism as incoherent - 'the contradiction of the Scholastics, that it is both as a whole in the whole body and as a whole in each of its parts' (1 July 1643, repr. in Shapiro 2007a, p. 72) - so it can be safely assumed that she would not have endorsed Descartes' view if she had thought that it entailed a commitment to holenmerism.

${ }^{5}$ For Descartes and the Scholastics, though not for Aristotle, strictly speaking only God is capable of independent existence. Created substances depend for their existence on God, who has multiple principal attributes. I will set this issue aside since it does not affect the content of any of the arguments discussed here, which pertain only to finite substances. 
possess two natures, neither reducible to or equivalent to the other, Elisabeth can consistently hold that the soul is both conscious and extended, without endorsing materialism. Not only is she under no theoretical pressure to reduce thought to extension, she need not prioritise one of these attributes as the real, underlying principal attribute. In her case, raising the question of multiple natures is therefore compatible with a kind of dualism.

The arguments of the Meditations nowhere explicitly defend Descartes' substance-mode ontology. Having established that our conscious states are inseparable from us, and later proved to her satisfaction the existence of God and the external world, the meditator concludes in favour of the real distinction of mind and body on the grounds that they have very different properties. The mind is indivisible, the body, divisible. The mind is clearly and distinctly perceived to be thinking and non-extended, the body is distinctly perceived to be extended and non-thinking. ${ }^{6}$ While a case is built for the distinction between mind and body, very little space is devoted to explaining their union. It may be that Descartes saw no need to defend or explain either his substance-mode ontology or the union of mind and body because his main audience, the Scholastics, already accepted these assumptions. Scholastic hylomorphism takes soul-body union entirely for granted. All matter is informed by some form, and matter which is ensouled is just a special case of information. Scholastics took the controversial issue to be the real distinction between, not the union of, mind and body. Elisabeth, by contrast, queried hylomorphism and pressed for an explanation of the union and interaction of mind and body.

\section{Mind and Body in the Descartes-Elisabeth Correspondence}

In her first letter to Descartes, Elisabeth raised a problem of mind-body interaction for his dualism as presented in the Meditations, which she had recently read. Assuming the mechanistic physics they both subscribed to, she asked how its explanation of motion could be extended to the case of mental states causing motion in the body.

'I ask you please to tell me how the soul of a human being (it being only a thinking substance) can determine the bodily spirits, in order to bring about voluntary actions. For it seems that all determination of movement happens though the impulsion of the thing moved, by the manner in which it is pushed by that which moves it, or else by the particular qualities and shape of the surface of the latter. Physical contact is required for the first two conditions, extension for the third. You entirely exclude the one [extension] from the notion you have of the soul, and the other [physical contact] appears to me incompatible with an immaterial thing. This is why I ask you for a more precise definition... of its substance separate from its action, that is, from thought' (Elisabeth to Descartes, 6 May 1643, repr. in Shapiro 2007a, p. 62)

Descartes answered that mind-body interaction is only explicable with reference to mind-body union, a primitive notion in its own right, and not to be understood on the model of interaction between bodies. He invoked the Scholastic conception of gravity, which acts on a body without physical contact, as a model for understanding how the mind acts on the body (Descartes to Elisabeth, 21 May 1643, repr. in Shapiro 2007a, p. 66). Elisabeth responded with polite puzzlement.

'I admit that it would be easier for me to concede matter and extension to the soul than to concede the capacity to move a body and be moved by it to an immaterial thing. For, if the first is achieved through information, it would be necessary that the spirits, which cause the movements, were intelligent, a capacity you accord to nothing corporeal. And even though, in your Metaphysical Meditations, you show the possibility of the second, it is altogether

\footnotetext{
6 This interpretation of Descartes' epistemological argument, different varieties of which are advanced by Wilson (1978 pp. 197-8) and Williams (1979, p. 113) is in my view preferable to one which takes Descartes to infer dualism from our ability to doubt the body but not the mind. The latter yields an obviously invalid argument. Wilson's and Williams' interpretations are more charitable to Descartes.
} 
very difficult to understand that a soul, as you have described it, after having had the faculty and the custom of reasoning well, can lose all of this by some vapours, and that, being able to subsist without the body, and having nothing in common with it, the soul is still so governed by it.' (Elisabeth to Descartes, 10 June 1643, repr. in Shapiro 2007a, p. 68)

It is easy to see how Elisabeth might be read as a materialist here. Her remarks strikingly resemble, for example, those of the self-professed materialist Margaret Cavendish some twenty years later: 'I cannot conceive, how a Spirit ... can have the effects of a body, being none it self' (1664, $p$. 197). Although the materialist reading appears natural at first sight, I think there is more to the story. According to my alternative interpretation, Elisabeth's views are Cartesian in spirit and compatible with dualism. In addition, I argue, Elisabeth made a positive proposal for a new direction a Cartesian-inspired dualist might take while distinguishing herself more clearly from Scholasticism than even Descartes himself had done.

\section{A Modified Cartesianism: Highlighting Elisabeth's Anti-Scholastic Metaphysical Views}

I read Elisabeth as favouring a roughly Cartesian metaphysics with some modifications, primarily to purge it of the remnants of Scholasticism. While on balance she preferred Descartes' account to those of his Scholastic and his materialist opponents, she nevertheless believed more research into the nature of both the body and the mind was necessary. She had already asked Descartes, in her very first letter, for 'a more precise definition of the soul', and would continue to press for one over the course of their exchange. She is best interpreted as proposing that the solution to the mind-body problem must lie in further empirical and philosophical investigation into the properties of the mind.

What speaks in favour of my interpretation of Elisabeth? One clue is that in the passage quoted above, she appears to be resisting typically Scholastic explanations in terms of a formal cause. As a proponent of mechanistic physics, Elisabeth refers to her opposition to the hylomorphic doctrine of 'information', that is, form imposing itself on matter. Shapiro (2007, p. 68, n. 12) suggests that 'information' and 'spirits' might equally be taken to refer to Stoic pneuma. Given that Elisabeth was addressing Descartes' views on mind-body interaction, and specified 'bodily spirits' in her previous letter, it seems more plausible that she meant to refer to the 'animal spirits' Descartes invokes, an idea derived from Galen (Kühn (ed.) 1822). Descartes, who had a keen interest in anatomy, strove for a philosophy of mind which, unlike hylomorphism, was in harmony with the mechanistic physiological science of his day. He proposed a conception of the nervous system as thin tubes containing animal spirits with the power to move ventricles in the brain (1985 [1633], 1985 [1647/8]). Elisabeth wanted to know how the immaterial soul could make these animal spirits move. She rebuffed Descartes' attempts to frame mind-body causation in terms of the Aristotelian conception of gravity. Aristotelian gravity, after all, was supposed to be a kind of formal causation, a throwback to hylomorphism. Elisabeth's preferred mechanistic physics only countenanced the efficient cause, and an explanation in terms of efficient causes is what she wanted Descartes to provide. What exactly, she asked, is the mechanistic, efficient cause of the movement of the animal spirits, since it certainly is not any such thing as an Aristotelian formal cause?

Another clue is found in the sentences immediately preceding the ones quoted above.

'[l am] unable to comprehend, by appeal to the idea you once had of heaviness, the idea through which we must judge how the soul (nonextended and immaterial) can move the body; nor why this power to carry the body toward the centre of the earth, which you earlier falsely attributed to a body as a quality, should sooner persuade us that a body can be pushed by some immaterial thing, than the demonstration of a contrary truth (which you promise in your physics) should confirm us in the opinion of its impossibility ... since no material cause presents itself to the senses, one would then attribute this power to its contrary, an immaterial cause. But I nevertheless have never been able to conceive of such an immaterial thing as anything other than a negation of matter which cannot have any communication with it.' (Elisabeth to Descartes, 10 June 1643, repr. in Shapiro 2007a, p. 68) 
Echoing Descartes' own complaint that the Scholastics' invocation of 'real qualities' was a sham explanation, 'just the same as saying we perceive something in the objects whose nature we do not know' (1985 [1644], p. 218), I read Elisabeth here as making a comparable complaint about the Aristotelian conception of gravity. No useful insight is to be found in it, since it reveals nothing positive about the nature of the causes involved. Elisabeth can be seen to express dissatisfaction with Descartes' use of the merely negative predicate 'immaterial', which tells us nothing about the substance it applies to other than that it is not material. But Descartes, who sometimes used 'immaterial' interchangeably with 'thinking', apparently took it to characterise the nature of a substance. As I interpret this passage, Elisabeth challenged Descartes in this letter to provide some positive reason to equate 'immaterial' with 'thinking' or 'conscious'. We find her obliquely drawing attention to the fact that the predicates might have distinct extensions: Aristotelians thought of gravity as immaterial but non-conscious. Descartes' example contradicts rather than corroborates his case. And merely negative characterisations of substances leave us in the dark as to their nature, characteristic behaviour and causal powers. Elisabeth asked Descartes to leave such quasi-Scholastic moves behind, and provide an up-to-date explanation in terms of efficient causes, compatible with mechanistic physics, of the relationship between mind and body.

Descartes, to Elisabeth's disappointment, never did provide the account she had requested. Yet it seems that he saw her point to some extent, as he corrected himself in his next letter, admitting that the gravity analogy had been unhelpful. What he had meant to say, he claimed, was that 'things which pertain to the union of the soul and body are known only obscurely by the understanding ... but they are known very clearly by the senses' (Descartes 28 June 1643, repr. in Shapiro 2007a, p. 71). That is, as Rozemond (1998, p. 183) puts it, mind-body causation can only be understood phenomenologically.

Elisabeth conceded, in her reply, that 'the senses show me that the soul moves the body' but remained dissatisfied because 'they teach me nothing (no more than do the understanding and the imagination) of the way in which it does so' (Elisabeth 1 July 1643, repr. in Shapiro 2007a, p. 72). Her mention of the 'senses' refers to the mental mode of phenomenological awareness of mind-body interaction - that is, the subjective experience of such interaction from the inside out, rather than as an outside observer - as can be seen from her grouping them with other Cartesian modes of the mind, imagination and understanding. So her words should not be taken to imply that third-personal scientific observations could not form the basis of a solution to the interaction problem. On the contrary, a more scientifically informed account of the soul is exactly what Elisabeth asks for next.

'I think that there are some properties of the soul, which are unknown to us, which could perhaps overturn what your Metaphysical Meditations persuaded me of by such good reasoning: the nonextendedness of the soul. This doubt seems to be founded on the rule that you give there, in speaking of the true and the false, that all error comes to us in forming judgments about that which we do not perceive well enough. Though extension is not necessary to thought, neither is it at all repugnant to it, and so it could be suited to some other function of the soul which is no less $^{7}$ essential to it.' (Elisabeth 1 July 1643, repr. in Shapiro 2007a, p. 72)

I read this passage as Elisabeth contesting Descartes' claim that the 'nonextendedness' of the soul is clearly and distinctly perceived. Though agreeing with Descartes that thinking could not be explained reductively by mechanistic physics (Descartes 1985 [1637] p. 140) - 'extension is not necessary to thought' - she considered it logically consistent to suppose both thought and extension belonged to the soul. Descartes' Scholastic substance-attribute ontology dictated that each finite substance must have exactly one principal attribute to which all its modes belong (Descartes 1985 [1644] p. 210). But Elisabeth, who yearned to replace Scholasticism with mechanistic science

7 This is translated 'less essential to her' in Blom's edition. The pronoun 'her' in his translation refers to the feminine French word for the soul (âme). 
and a philosophy respectful of it, is best interpreted here as challenging this dogma. From the point of view of first philosophy, Elisabeth argued, the proposition that something extended thinks is not contradictory or clearly and distinctly false ('repugnant'). She took this proposition, that a substance has both extension and thought as its principal ('essential') attributes without one having to be reduced to the other, to have great potential for making Cartesian philosophy consistent with modern physics.

On my reading, Elisabeth's call for further investigation into the 'unknown properties' of the soul in order that it can be 'perceived well enough' was likely intended to have an empirical component. While praising Descartes' first-philosophy based investigations, she clearly stated that gaps in our knowledge remained, gaps which we reflexively fill in erroneous ways. It seems that the first-philosophy method had been exhausted and yielded insufficient data. To keep us from error, according to Elisabeth, we must come to clearly perceive the soul by other means.

Twice Elisabeth asked Descartes for improved definitions of the soul not relying on merely negative, uninformative descriptions like 'nonextendedness' or 'immateriality'. Once she suggested, quite clearly but so briefly that it is easily missed, that even 'thinking' is an insufficient definition of a primary attribute for the soul. Thought, she claimed, is not an attribute but an 'action'. Thinking is something which a mental substance does. It does not follow that thinking constitutes the essence of what a mental substance is. Elisabeth gave two examples of cases where a soul might exist without thinking: before birth, and while unconscious. 'I ask you for a more precise definition of the soul ... of its substance separate from its action, that is, from thought. For even if we were to suppose them inseparable (which is however difficult to prove in the mother's womb or in great fainting spells) ... we could, in considering them apart, acquire a more perfect idea of them' (Elisabeth 6 May 1643, repr. in Shapiro 2007a, p. 62).

Elisabeth appears to have held that there was insufficiently strong philosophical and empirical evidence to identify the principal attribute of mental substance. Since neither immateriality nor thought were good candidates for the principal attribute of mental substance, in her view, this attribute remained to be discovered, and might be compatible with that of extension.

\section{Against the Materialist Interpretation of Elisabeth}

Shapiro, who reads Elisabeth as a materialist, admits that Elisabeth was never a reductive materialist, since she held that 'extension is not necessary to thought' (2007b, p. 42). Her resistance to reductionism puts Elisabeth at odds with the materialists of her day. The prominent seventeenthcentury materialists Hobbes, Gassendi and Cavendish ${ }^{8}$ advocated reductionism about the mind, predicting that a future science would explain all mental phenomena in terms of interaction between material bodies. We can be sure that Elisabeth had not read Cavendish, who was five years her junior and only began to work on materialism in the 1660s. But her later letters to Descartes reveal that she was familiar with the works of Hobbes and Gassendi. Were she a materialist, we might expect her to 'find their views appealing' as Tollefsen (1999, p. 73) conjectures. In fact we see Elisabeth being dismissive in the extreme of exactly two sets of Objections to the Meditations: those by Hobbes and those by Gassendi. Upon being sent the French edition by Descartes, Elisabeth wrote, 'M. Gassendi, who has such a reputation for knowledge, made, after the Englishman, the least reasonable objections of all' (Elisabeth, 5 December 1647, repr. in Shapiro 2007a, p. 167). Her verdict is not wholly surprising given the respect for Cartesian dualism she had expressed in earlier letters. Where these reductive materialists had disparaged Descartes' arguments for the real distinction, Elisabeth praised those arguments as persuasive and 'such good reasoning' (Elisabeth 1 July 1643, repr. in Shapiro 2007a, p. 72). In addition to her negative claims about Hobbes and Gassendi, in 1647 Elisabeth continued to urge refinements to Cartesian physics and dualism. About a treatise on physics by Descartes' disciple Hogelande, she raised the concern

8 Cavendish's early philosophical writings (1664) suggest reductive materialism: she considers our minds and thoughts to be entirely located in the natural, material world (see also Detlefsen 2007), But Cavendish is open to the possibility that immaterial things, such as God, exist outside nature, outside the comprehension of our material minds (1664 p. 315). An anonymous referee also points out that the reductionist interpretation fits less well with her later Observations (2001 [1668]). 
that 'the subtle matter, which [Hogelande] supposes to be enveloped in a coarser one by the heat of fire or by fermentation, is nevertheless corporeal and receives its pressure or its movement by the quantity and surfaces of its small parts. The soul, which is immaterial, could not do this' (Elisabeth May 1647, repr. in Shapiro 2007a, p. 163).

Although these facts are compatible with an interpretation of Elisabeth as an atypical, nonreductive materialist (or, alternatively, a property dualist), other statements of hers are hard to square with any sort of materialist reading. Elisabeth maintained that thought is logically compatible with extension, but a completely separate function from it, and not necessary to it. It is difficult to see how a view according to which matter is not necessary to thought could be a kind of materialism. Although her letter from May 1647 quoted above makes clear that she continued to puzzle over the interaction problem, in her later letters Elisabeth appears to have endorsed a dualism even stronger than property dualism, and spoke of the soul as being able to exist without the body. Opposing the views of Descartes' English critic Digby, she wrote, 'it is impossible to doubt that it [the soul] will not be more happy after its separation from the body' (Elisabeth 28 October 1645, repr. in Shapiro 2007a, p. 123).

\section{A Dualist Interpretation}

Elisabeth is best interpreted as a Cartesian thinker, and a dualist, but one who strove for a more consistent application of the methods of the new science and philosophy, aiming to bring the two into harmony to account for the interaction of mind and body. An opponent of the old Aristotelian paradigms, she was palpably disappointed that Descartes' answer to her query harked back to the old obscurantism of formal causes and real qualities. Since first philosophy could not answer the question of mind-body interaction, her preferred solution was to explore further empirical enquiry into the properties of the mind.

Although she preferred Descartes' view to that of his materialist opponents as well as to that of the hidebound seventeenth-century Scholastics, Elisabeth was not a Cartesian dualist in the strict sense. Her statement that 'a soul ... after having had the faculty and the custom of reasoning well, can lose all of this by some vapours' indicates that she found it difficult to accept Descartes' thesis that the understanding operates completely independently of the body. What Wilson calls Descartes' 'robust' dualism (Wilson 1978, p. 131), according to which purely intellectual thought has no material correlate, cannot easily make sense of bodily states interfering with abstract reasoning. Still, Elisabeth contends, we can see such interference occurring, and it calls out for explanation. For this reason among others, Broad (2002, p. 27) regards Elisabeth's position as most akin to that of Henry More, a dualist who independently proposed that the soul might be extended some sixteen years later (More 1659). More believed that mental substances had the property of extension, allowing them to pervade and operate upon bodies. Elisabeth's brief remark that 'extension ... could be suited to some other function of the soul' might be taken to suggest a view similar to or anticipating More's. We know from their mutual acquaintances Francis Mercury van Helmont and Anne Conway that Elisabeth read and approved of More's works much later, around 1670-1 (Broad 2002, pp. 27-8).

Elisabeth, even in 1643, had already expressed her openness to considering the overthrow of certain metaphysical principles, such as 'each finite substance has exactly one principal attribute', if giving them up might yield a better answer to the mind-body problem compatible with the new physics. Her attitude was one which in the twentieth and twenty-first centuries we would call naturalistic. She suggested that the outcome of empirical investigations into 'unknown properties of the soul' might 'overturn what your Metaphysical Meditations persuaded me of by such good reasoning' (Elisabeth 1 July 1643, repr. in Shapiro 2007a, p. 72). In this, Elisabeth resembles contemporary naturalistic dualists, who propose substance dualism as a best explanation of the relationship between current physics and current psychology (Janssen-Lauret 2017, Janssen-Lauret and Bleau under contract). 


\section{Conclusion}

Elisabeth of Bohemia's letters to Descartes reveal a novel, consistent and interesting solution to the mind-body problem. Far from being just a Cartesian handmaiden or an interlocutor who simply raised objections without making a positive proposal, Elisabeth was a Cartesian sympathiser and an original metaphysician. Elisabeth is best understood, not as a materialist as some of her statements might suggest, but as a philosopher mostly sympathetic to dualism who called for further investigation into the properties of the mind. Elisabeth emphatically renounced Aristotelian hylomorphism about both physics and the human person. With her strong adherence to the mechanistic account of bodily motion, we can see her urging Descartes to explain how the soul causes the bodily spirits to move as a demand for an explanation not relying on Aristotelian formal causation, but only the efficient causation used by the empirical science of their day. Elisabeth proposed that the soul may have multiple natures, both thinking and extended. Since she did not, like her materialistic contemporaries, believe that thought is reducible to interaction between bodies, I suggest her raising the question that the mind may have two natures does not imply materialism, the thesis that the two natures are reducible to one. Rather, Elisabeth called into doubt the vestigial Scholasticism of Descartes underlying ontology of substances, attributes and modes. According to her, since it is consistent to suppose that something thinking should be extended, Descartes' insistence that each (finite) substance has exactly one principal attribute to which all its modes belong is a piece of Scholastic dogma for which there is no independent evidence. Elisabeth held that the true nature of the soul is still unknown to us, and that Descartes overlooked this fact since he incorrectly categorises the 'action' of thought as an attribute, and identified it without good reason with the merely negative, uninformative property of immateriality. Elisabeth's call to arms for empirical research into the nature of the mind, without presupposing that thought is reducible to physical motion, adumbrates recent developments in naturalistic dualism which proposes substance dualism as a best interpretation of the difference in logical form between physics and current psychology.

Acknowledgements: I am very grateful to Emily Thomas, the audience at the Early Modern Women on Science and Philosophy conference, and an anonymous referee for Cambridge University Press for their thoughts and suggestions.

\section{References}

Anscombe, Elizabeth, and Geach, Peter (eds. and trs.) 1954. Descartes: Philosophical Writings, Nelson.

Blom, John J. (ed.) 1978. Descartes: His Moral Philosophy and Psychology. The Harvester Press.

Broad, Jacqueline 2002. Women Philosophers of the Seventeenth Century. Cambridge University Press.

Cavendish, Margaret 1664. Philosophical Letters. William Wilson.

Cavendish, Margaret 2001 [1668]. Observations upon Experimental Philosophy. Eileen O'Neill (ed.), Cambridge University Press.

Cottingham, John, Stoothoff, Robert, and Murdoch, Dugald (eds.) 1985. The Philosophical Writings of Descartes. Cambridge University Press. 
Pre-publication draft for E. Thomas (ed.) Early Modern Women on Metaphysics, CUP11

Descartes, René, 1985 [1633] Treatise on Man, in Cottingham, Stoothoff and Murdoch (eds.), volume I, pp. 99-108.

Descartes, René, 1985 [1637] Discourse on the Method, in Cottingham, Stoothoff and Murdoch (eds.), volume I, pp. 109-151.

Descartes, René, 1985 [1641] Meditations on First Philosophy, in Cottingham, Stoothoff and Murdoch (eds.), volume II.

Descartes, René, 1985 [1644] Principles of Philosophy, in Cottingham, Stoothoff and Murdoch (eds.), volume I.

Descartes, René, 1985 [1647/8] Description of the Human Body, in Cottingham, Stoothoff and Murdoch (eds.), volume I, pp. 314-24.

Descartes, René, 1985 [1649] The Passions of the Soul, in Cottingham, Stoothoff and Murdoch (eds.), volume I, pp. 325-404.

Descartes, René 1643-1649, Correspondence with Elisabeth, in Shapiro 2007a.

Detlefsen, Karen 2007. 'Reason and Freedom: Margaret Cavendish on the Order and Disorder of Nature', Archiv für Geschichte der Philosophie, 89, pp. 157-191.

Princess Elisabeth of Bohemia 1643-1649. Correspondence with Descartes, in Shapiro 2007a.

Harth, Erica 1992. Cartesian Women. Cornell University Press.

Janssen-Lauret, Frederique 2017. 'Logical Form, the First Person, and Naturalism about Psychology: The Case Against Physicalist Imperialism' in M. Fernandez Pinto, U. Maki, and A. Walsh (eds.) Scientific Imperialism, Routledge, under contract. Available online at https://www.academia.edu/25744572/Logical Form the First Person and Naturalism About Psychology

Janssen-Lauret, Frederique, and Bleau, Renée, under contract. The Indispensable Self. Palgrave Macmillan, Psychology Series.

King, Margaret, and Rabil, Albert 2007. 'The Other Voice in Early Modern Europe: Introduction to the Series' in Shapiro 2007a pp. ix-xxviii.

Kühn, C.G. (ed.) 1822. Claudii Galeni Opera Omnia, vol. 3, Leipzig Cnobloch.

More, Henry 1659. The Immortality of the Soul. J. Flesher.

Nye, Andrea 1999. The Princess and the Philosopher: Letters of Elisabeth of the Palatine to René Descartes. Rowman and Littlefield.

Pasnau, Robert 2011. Metaphysical Themes 1274-1671. Oxford University Press.

Ready, Kathryn 2002. 'Damaris Cudworth Masham, Catharine Trotter Cockburn, and the Feminist Legacy of Locke's Theory of Personal Identity', Eighteenth-Century Studies 35, pp. 563-76.

Rozemond, Marleen 1998. Descartes's Dualism. Harvard University Press. 
Pre-publication draft for E. Thomas (ed.) Early Modern Women on Metaphysics, CUP12 Rozemond, Marleen 2003. 'Descartes, Mind-Body Union, and Holenmerism', Philosophical Topics 31, pp. 343-367.

Rudder Baker, Lynn 1995. 'Need a Christian be a Mind/body Dualist?' Faith and Philosophy, 12(4), pp. 489-504.

Shapiro, Lisa (ed.) 2007a. The Correspondence between Princess Elisabeth of Bohemia and René Descartes. University of Chicago Press.

Shapiro, Lisa 2007b. 'Volume Editor's Introduction' in Shapiro 2007a pp. 1-60.

Tollefsen, Deborah 1999. 'Princess Elisabeth and the Problem of Mind-Body Interaction' Hypatia 14(3), pp. 59-77.

van Inwagen, Peter 1978. 'The Possibility of Resurrection'. International Journal for Philosophy of Religion, 9(2), pp. 114-121.

van Schurman, Anna Maria 1659. The Learned Maid, or Whether a Maid may be a Scholar. John Redmayne.

Williams, Bernard 1979. Descartes: The Project of Pure Enquiry. Penguin.

Wilson, Margaret Dauler 1978. Descartes. Routledge. 